\title{
Mengembangkan Kemampuan Pemahaman Konsep Peserta Didik Melalui Pembelajaran Berbasis VCD
}

\author{
Farida \\ ${ }^{1}$ IAIN Raden Intan Lampung; farida@iainradenintan.ac.id \\ Submitted : 12-02-2015, Revised : 24-04-2015, Accepted : 16-06-2015
}

\begin{abstract}
There are several factors that with low learning outcomes of learners, the most important is the low interest of learners to follow the lesson well and earnestly. Lack of strong motivation to be one cause of low interest learners learners. This study aims to improve the ability to understand the mathematical concepts of the subject matter kesebangunan. The benefits of this research is to provide input in choosing a varied learning model that can improve the learning outcomes of learners mathematics as well as information materials for other researchers.

The research method used is experimental research with right $t$ test with population class $I X$ $S M P$ Negeri 3 Bandar Lampung. The results showed that learning mathematics with VCD media learning on the ability of understanding the concept of class IX students SMP Negeri 3 Bandar Lampung semester I on the subject matter kesebangunan more effective than conventional learning, it is seen from the ability to understand the concept of learners better than conventional learning. Thus learning mathematics with VCD media learning on the subject matter kesebangunan can be used as an alternative method in learning in order to increase the variety of teaching methods in the effort to train the skills of reasoning and communication of learners and improve learning outcomes of learners.
\end{abstract}

Keywords: VCD; Learning; Understanding; concept.

\begin{abstract}
Abstrak
Ada beberapa faktor yang dengan rendahnya hasil belajar peserta didik, yang paling utama adalah rendahnya minat peserta didik untuk mengikuti pelajaran dengan baik dan sungguh-sungguh. Kurang adanya motivasi yang kuat menjadi salah satu penyebab terhadap rendahnya minat belajar peserta didik. Penelitian ini bertujuan untuk meningkatkan kemampuan pemahaman konsep matematika materi pokok kesebangunan. Manfaat dari penelitian ini yaitu memberikan masukan dalam memilih model pembelajaran yang bervariasi yang dapat meningkatkan hasil belajar matematika peserta didik serta sebagai bahan informasi bagi peneliti lain.

Metode penelitian yang digunakan adalah penelitian eksperimen dengan uji t pihak kanan dengan populasi kelas IX SMP Negeri 3 Bandar Lampung. Hasil penelitian menunjukkan bahwa pembelajaran matematika dengan media VCD pembelajaran terhadap kemampuan pemahaman konsep peserta didik kelas IXSMP Negeri 3 Bandar Lampung semester I pada materi pokok kesebangunan lebih efektif dibandingkan pembelajaran konvensional, hal ini terlihat dari kemampuan pemahaman konsep peserta didik yang lebih baik dibandingkan pembelajaran konvensional. Dengan demikian pembelajaran matematika dengan media VCD pembelajaran pada materi pokok kesebangunan dapat
\end{abstract}


dijadikan suatu metode alternative dalam pembelajaran guna menambah variasi metode mengajar dalam upaya melatih keterampilan penalaran dan komunikasi peserta didik dan meningkatkan hasil belajar peserta didik.

Kata kunci: VCD; pembelajaran; pemahaman; konsep.

\section{PENDAHULUAN}

Proses pembelajaran merupakan rangkaian kegiatan komunikasi antara peserta didik dan guru. Proses pembelajaran dikatakan efektif apabila terjadi transfer belajar yaitu materi yang disajikan guru dapat diserap ke dalam struktur kognitif peserta didik. Peserta didik dapat mengetahui materi tersebut tidak hanya terbatas pada tahap ingatan saja tanpa pengertian (rote learning) tetapi bahan pelajaran dapat diserap secara bermakna (meaning learning). Agar terjadi transfer belajar yang efektif maka kondisi fisik dan psikis dari setiap individu peserta didik harus sesuai dengan materi yang dipelajarinya.

Berdasarkan wawancara dengan guru-guru ada beberapa faktor yang berkaitan dengan rendahnya hasil belajar peserta didik, yang paling utama adalah rendahnya minat peserta didik untuk mengikuti pelajaran dengan baik dan sungguh-sungguh. Kurang adanya motivasi yang kuat menjadi salah satu penyebab terhadap rendahnya minat belajar peserta didik. Faktor lain yang juga berpengaruh adalah cara mengajar guru yang kurang menarik. Selain itu lingkungan serta sarana dan prasarana pendukung juga ikut mempengaruhi terhadap rendahnya hasil belajar peserta didik.

Dalam pembelajaran di sekolah guru merupakan salah satu faktor yang cukup penting dalam proses pembelajaran. Guru hendaknya memilih dan menggunakan strategi pendekatan dan media pembelajaran yang tepat. Selain menggunakan strategi dan media pembelajaran yang tepat juga harus memperhatikan pembelajaran yang banyak melibatkan peserta didik aktif dalam belajar, baik mental, fisik maupun sosial dan dapat menggunakan kemampuan bernalar maupun berpikir. Di samping itu untuk menciptakan kondisi dan situasi yang memungkinkan pembelajaran berlangsung secara aktif dalam kelas adalah dengan memperhatikan media pembelajarannya. Untuk mencapai tujuan yang diharapkan tersebut tidak hanya dibutuhkan kompetensi guru yang memadai, tetapi harus didukung dengan media pembelajaran yang menarik. Untuk memenuhi kebutuhan tersebut seorang guru dituntut untuk menyediakan atau membuat media pembelajaran yang praktis dan mudah untuk digunakan dalam kegiatan belajar mengajar.

Media menurut Hamidjojo merupakan semua bentuk perantara yang digunakan oleh manusia untuk menyampaikan atau menyebar ide, gagasan, atau pendapat sehingga ide, gagasan, atau pendapat yang dikemukakan itu sampai kepada penerima yang dituju (Arsyad, 2005:4). Dalam kegiatan pembelajaran, media merupakan salah satu sumber belajar yang dapat menyampaikan pesan-pesan pendidikan kepada para peserta didik. Perbedaan gaya belajar, minat, intelegensi, keterbatasan indera, hambatan jarak dan waktu dan lain-lain dapat dibantu dengan memanfaatkan media. Oleh karena itu kehadiran media dalam pembelajaran tidak mungkin diabaikan, kehadiran media sangat penting terutama dalam menyajikan model kompetensi target yang ingin dicapai (modelling). Media juga diperlukan untuk 
mengembangkan kemampuan bertanya peserta didik (questioning) dalam menggali informasi, mengecek pemahaman dan meningkatkan respon peserta didik.

Pemilihan media yang tepat sangat memberikan peranan dalam pembelajaran. Selama ini media pembelajaran yang dipakai adalah buku-buku panduan atau dengan alat peraga. Tetapi seiring dengan berkembangnya teknologi, media pembelajaran tersebut kurang menarik perhatian dan minat peserta didik. Untuk itu diperlukan suatu media pembelajaran yang dapat lebih menarik perhatian dan minat peserta didik tanpa mengurangi fungsi media pembelajaran secara umum. Dalam hal ini media pembelajaran yang dibutuhkan juga harus sudah populer di masyarakat, khususnya di kalangan peserta didik dan guru.

Menurut KBBI (Balai Pustaka, 1990:1120) visualisasi diartikan sebagai pengungkapan gagasan atau perasaan dengan menggunakan bentuk gambar grafik, dan sebagainya atau suatu proses pengubahan konsep menjadi gambar untuk disajikan lewat televisi oleh produsen. VCD adalah alatyang digunakan untuk menyajikan gambar atau tulisan dan animasi melalui TV. VCD adalah sebuah alat yang sudah cukup populer di kalangan masyarakat umum. Penggunaan media pembelajaran matematika yang berbentuk VCD memungkinkan digunakan dalam berbagai keadaan tempat, baik di sekolah maupun di rumah, serta yang paling utama adalah dapat memenuhi nilai atau fungsi media pembelajaran secara umum. Dengan media VCD, diharapkan peserta didik akan merasa nyaman ketika memperoleh mata pelajaran matematika. Setelah itu tentunya peserta didik akan menjadi tertarik sehingga secara perlahan perasaan takut terhadap mata pelajaran matematika akan luntur dan akhirnya hilang. Selain itu dengan media VCD diharapkan peserta didik akan menjadi lebih mudah mengerti dengan mata pelajaran matematika.

Menurut guru kelas IX, berpendapat bahwa peserta didik kelas IX SMP Negeri 3 Bandar Lampung mengalami banyak kesulitan pada materi kesebangunan. Kenyataan ini dapat dilihat dari hasil belajar pada materi pokok ini pada tahun-tahun sebelumnya, yaitu masih banyak peserta didik yang belum mencapai batas tuntas yaitu 65 . Kesulitan yang dialami dikarenakan kurangnya pemahaman dan kekurangtertarikan peserta didik pada pelajaran matematika. Sebagian besar peserta didik hanya menghafal rumus saja sehingga mereka kesulitan dalam menyelesaikan soal-soal aplikasi khususnya dalam aspek pemahaman konsep. Salah satu faktor kekurangtertarikan peserta didik adalah suasana kelas yang pasif serta sebagian peserta didik terlanjur menganggap bahwa matematika adalah pelajaran yang sulit sehingga kecenderungan kelas menjadi tegang, karena itulah diperlukan guru yang aktif dan kreatif dalam kegiatan pembelajaran sehingga peserta didik dapat menguasai materi dan mencapai tujuan pembelajaran yang ditetapkan.

\section{METODE PENELITIAN}

Penelitian ini merupakan penelitian kuantitatif. Populasi dalam penelitian ini adalah peserta didik kelas IX SMP Negeri 3 Bandar Lampung Tahun Pelajaran 2014/2015.Sampel yang digunakan dalam penelitian ini adalah sebagian dari peserta didik SMP Negeri 3 Bandar Lampung. Pengambilan sampel dalam penelitian ini dengan memilih beberapa kelas dan dipilih secara acak. 
Dalam penelitian ini dipilih satu kelas sebagai kelas eksperimen yaitu kelas IX E dan satu kelas sebagai kelas kontrol yaitu kelas IX F. Kelompok kelas eksperimen dikenai pembelajaran dengan media VCD dan kelompok kelas kontrol dikenai pembelajaran konvensional. Selain itu, dipilih satu kelas lagi sebagai kelas uji coba yaitu kelas IX D.

Validitas tes diketahui dengan menggunakan rumus korelasi product moment yaitu :

$$
r_{x y}=\frac{N \sum X Y-\left(\sum X\right)\left(\sum Y\right)}{\sqrt{\left[N \sum X^{2}-\left(\sum X\right)^{2}\right\}\left\{N \sum Y^{2}-\left(\sum Y\right)^{2}\right.}}
$$

Untuk mengetahui reliabilitas tes digunakan rumus:

$$
r_{11}=\left[\frac{k}{k-1}\right]\left[1-\frac{\sum \sigma_{b}^{2}}{\sigma_{t}^{2}}\right]
$$

Jawaban terhadap soal bentuk uraian secara teoritis tidak ada yang salah mutlak, sehingga derajat kebenaran jawaban tersebut akan berperangkat sesuai dengan mutu jawaban masing-masing peserta didik.

$$
\text { Rumus yang digunakan: }
$$

$$
\mathrm{TK}=\frac{\text { Banyaknyasiswa yang gagal }}{\text { Banyaknyasiswa yang mengikutites }} \times 100 \%
$$

(Sudjana, 1996:239).

Untuk menentukan daya pembeda soal untuk tes yang berbentuk uraian menggunakan rumus uji t, yaitu sebagai berikut.

$$
\mathrm{t}=\frac{M_{H}-M_{L}}{\sqrt{\left\{\frac{\sum x_{1}^{2}+\sum x_{2}^{2}}{n_{i}\left(n_{i}-1\right)}\right\}}}
$$

Hipotesis yang akan diuji sebagai berikut.

$H_{0}: \mu_{1} \leq \mu_{2}$ : Rata-rata skor tes kemampuan pemahaman konsep matematika pada materi pokok kesebangunan pada pembelajaran dengan media VCD pembelajaran sama atau lebih jelek dibanding pembelajaran konvensional.

$H_{1}: \mu_{1}>\mu_{2}$ : Rata-rata skor tes kemampuan pemahaman konsep matematika pada materi pokok kesebangunan pada pembelajaran dengan media VCD pembelajaran lebih baik dibanding pembelajaran konvensional. 
Ho diterima jika $t_{\text {hitung }}<t_{\text {tabel }}$, rumus $t_{\text {hitung }}$ yang digunakan sangat ditentukan hasil uji kesamaan variansi antar kedua kelompok, maka kemungkinan rumus $t_{\text {hitung }}$ yang digunakan adalah:

$\mathrm{H}_{0}$ diterima jika $t_{\text {hitung }}<t_{\text {tabel }}$, rumus $t_{\text {hitung }}$ yang digunakan sangat ditentukan hasil uji kesamaan variansi antar kedua kelompok, maka rumus $t_{\text {hitung }}$ yang digunakan adalah:

$$
\begin{aligned}
& t_{\text {hitung }}=\frac{\overline{X_{1}}-\overline{X_{2}}}{S \sqrt{\frac{1}{n_{1}}+\frac{1}{n_{2}}}}, t_{\text {tabel }}=t_{0,95\left(d k=n_{1}+n_{2}-2\right)} \\
& S^{2}=\frac{\left(n_{1}-1\right) S_{1}^{2}+\left(n_{2}-1\right) S_{2}^{2}}{n_{1}+n_{2}-2}
\end{aligned}
$$

Keterangan:

$\overline{X_{1}}$ : rata-rata nilai kelompok eksperimen

$\overline{X_{2}}$ : rata-rata nilai kelompok kontrol

$n_{1}$ : jumlah anggota kelompok eksperimen

$n_{2}$ : jumlah anggota kelompok kontrol

$S_{1}^{2}$ : varian kelompok eksperimen

$S_{2}^{2}$ : varian kelompok kontrol

$S^{2}$ : varian gabungan

(Sudjana, 1996:239).

Dari hasil perhitungan uji student yang dilakukan diperoleh nilai thitung $=2,375$. Harga ini dikonsultasikan dengan taraf signifikan $5 \%$ dan $\mathrm{dk}=39+39-2=76$, diperoleh $t_{\text {tabel }}=1,99$, dengan demikian thitung $>t_{1-\frac{1}{2} \alpha}$. Ini berarti kelas eksperimenlebihbaikdaripadakelaskontrol.

\section{HASIL PENELITIAN DAN PEMBAHASAN}

Dari analisis data awal diperoleh data yang berdistribusi normal dan homogen serta dari hasil uji kesamaan rata-rata menunjukkan bahwa $F_{\text {hitung }}<F_{\text {tabel, }}$ sehingga dapat disimpulkan bahwa kedua sampel berasal dari keadaan awal yang sama. Kemudian kedua sampel diberi perlakuan yang berbeda. Pada kelas eksperimen diberi perlakuan dengan pembelajaran dengan media VCD sedangkan pada kelas kontrol diberi perlakuan dengan model pembelajaran konvensional. 
Pada awal pertemuan di kelas eksperimen ada beberapa kendala, antara lain kurangnya kontrol waktu, selain itu pemahaman dari peserta didik tentang media VCD pembelajaran masih sangat kurang. Akan tetapi pada pertemuan yang kedua peserta didik dengan cepat dapat menyesuaikan pembelajaran dengan media VCD. Selanjutnya peserta didik paham dan antusias dalam mengikuti pembelajaran.

Dalam penelitian ini juga dilakukan pengamatan terhadap guru dan siswa dengan tujuan agar proses belajar mengajar dapat terkontrol dan sesuai dengan apa yang telah direncanakan. Pada awal pertemuan siswa kurang antusias dengan pembelajaran karena siswa telah terbiasa dengan pembelajaran konvensional. Pada pertemuan selanjutnya siswa terlihat lebih antusias. Bahkan siswa kelas eksperimen terlihat lebih antusias dalam mengikuti pembelajaran dibandingkan dengan siswa kelas kontrol.

Berdasarkan aspek perhatian peserta didik terhadap pengarahan guru ketika akan melaksanakan pembelajaran dengan VCD, tingkat kesungguhan peserta didik dalam memperhatikan pelajaran, peran peserta didik dalam proses belajar mengajar, kemampuan peserta didik dalam menganalisis masalah/soal untuk mencari cara penyelesaian, keruntutan dalam menyelesaikan soal, kelancaran peserta didik mengerjakan soal, semangat peserta didik selama pembelajaran berlangsung, banyaknya peserta didik yang bertanya selama pembelajaran berlangsung, kesukaan peserta didik mengikuti pembelajaran dengan VCD pembelajaran yang ditunjukkan dengan sikap gembira, sungguh-sungguh, serius, dan penuh tanggung jawab terhadap apa yang menjadi tugasnya, keaktifan peserta didik dalam pembelajaran dengan VCD pembelajaran, pada pertemuan 1 persentasenya adalah 62,5\%, pada pertemuan 2 persentasenya adalah $67,5 \%$, dan pada pertemuan 3 persentasenya mencapai $75 \%$. Itu menunjukkan bahwa terjadinya ketertarikan dan peningkatan minat, kemampuan, peserta didik dalam pembelajaran matematika dengan media VCD pembelajaran.

Pengamatan juga tidak hanya dilakukan pada siswa tapi juga dilakukan pada guru. Berdasarkan aspek kemampuan guru dalam membuka pelajaran, keruntutan penyampaian bahan ajar, kemampuan guru dalam menjawab pertanyaan dari peserta didik, kemampuan guru dalam menerapkan strategi pembelajaran dengan VCD pembelajaran, kemampuan guru saat melakukan evaluasi, peran guru dalam memotivasi peserta didik dalam pembelajaran, kemampuan guru dalam membimbing peserta didik saat mengerjakan soal, kemampuan guru dalam mengelola kelas, kemampuan guru dalam pemerataan perhatian kepada peserta didik selama pembelajaran berlangsung, kemampuan guru dalam memancing keaktifan peserta didik dalam pembelajaran dengan VCD pembelajaran, pada pertemuan 1 persentasenya adalah $67,5 \%$, pada pertemuan 2 persentasenya adalah $72,5 \%$, dan pada pertemuan 3 persentasenya mencapai $82,5 \%$. Itu menunjukkan bahwa terjadinya peningkatan kemampuan guru dalam mengelola pembelajaran matematika dengan media VCD pembelajaran.

Ternyata benar bahwa penggunaan media VCD pembelajaran dapat meningkatkan kemampuan siswa dalam menunjukkan pemahaman masalah, kemampuan siswa dalam mengorganisasi data dan memilih informasi yang relevan dalam pemahaman konsep, kemampuan membuat dan menafsirkan model matematika dari suatu masalah, dan 
kemampuan menyelesaikan masalah yang tidak rutin. Hal ini terlihat dari hasil belajar siswa kelas eksperimen yang lebih baik dibandingkan siswa kelas kontrol.

Pada uji ketuntasan pemahaman konsep dengan kriteria minimal tuntas 65 dari kriteria ketuntasan belajar matematika di SMP Negeri 3 Bandar Lampung, diperoleh $t_{\text {hitung }}=13,06$. Dengan taraf nyata $5 \%$ dan $\mathrm{dk}=37$ diperoleh $t_{\text {tabel }}=t_{(0,95)(38)}=1,69$. Karena $t_{\text {hitung }}>t_{\text {tabel }}$ maka Ho ditolak artinya rata-rata pemahaman konsep kelas eksperimen $\geq 65$ maka dapat disimpulkan bahwa pemahaman konsep kelas eksperimen telah melebihi minimal nilai ketuntasan belajar 65 .

Dari hasil perhitungan uji student yang dilakukan diperoleh nilai thitung $=2,375$. Harga ini dikonsultasikan dengan taraf signifikan $5 \%$ dan $\mathrm{dk}=39+39-2=76$, diperoleh tabel $=1,99$ dengan demikian $t_{\text {hitung }}>t_{\text {tabel. }}$. Berdasarkan data di atas dapat diketahui bahwa pemahaman konsep matematika peserta didik kelas IX F yang menerapkan pembelajaran dengan media VCD pembelajaran lebih baik daripada kemampuan matematika peserta didik kelas IX E yang dalam pembelajarannya menerapkan pembelajaran konvensional.

Pembelajaran dengan media VCD pembelajaran pada kelas eksperimen memiliki peningkatan hasil belajar yang lebih tinggi daripada kelompok kontrol, hal ini terjadi karena adanya penggunaan suatu media pembelajaran berupa VCD pembelajaran. Media VCD pembelajaran ini sangat berguna bagi guru dan peserta didik. Bagi guru alatini mempermudah dalam penyampaian materi pembelajaran. Penerapan pembelajaran dengan media VCD pembelajaran adalah alternatif pendekatan bagi peserta didik.

Sehingga dapat disimpulkan bahwa pembelajaran dengan media VCD pembelajaran efektif terhadap kemampuan pemahaman konsep matematika materi kesebangunan pada peserta didik kelas IX SMP Negeri 3 Bandar Lampung Tahun Ajaran 2014/2015.

\section{SIMPULAN DAN SARAN}

Berdasarkan hasil penelitian, pembelajaran matematika dengan media VCD pembelajaran lebih efektif dibandingkan pembelajaran konvensional pada kemampuan pemahaman konsep pada materi pokok kesebangunan pada peserta didik kelas IX SMP Negeri 3 Bandar Lampung. Berdasarkan hasil penelitian yang diperoleh, maka peneliti dapat mengemukakan saran-saran sebagaiberikut.

(1) Hendaknya guru dapat menerapkan pembelajaran dengan media VCD pembelajaran untuk lebih mengkonkritkan ide atau gagasan.

(2) Guru dapat memvariasikan media pembelajaran lainnya sehingga diperoleh metode yang lebih sesuai karakteristik materi pokok dan kondisi peserta didik.

(3) Bagi semua pihak yang berkompeten diharapkan untuk mengembangkan penelitian ini, baik sebagai penelitian lanjutan maupun penelitian lain. 


\section{DAFTAR PUSTAKA}

Arsyad, A. (2005). Media pembelajaran. Jakarta: Raja GrafindoPersada.

Sudjana. (1996). Metode Statistika. Bandung: Tarsito.

Tim penyusun KBBI. (1990). Kamus Besar Bahasa Indonesia. Jakarta: Balai Pustaka. 